\title{
近代日本における「文学部」の機能と構造
}

一帝国大学文学部を中心として一

\section{橋本 鉱市}

\section{1.はじめに一間逼の所在と分析視点一}

1991年の設置基準の大綱化は, 各大学に自己評価・自己点検を義務づけ, 教養課程 に関する規制を大幅に緩和して学部教育の改組・再編への機運をもたらした点で，日 本の高等教育システムを大きく变革する契機となった。各大学・学部はカリキュラム の編成面で，それぞれの理念・目的に基づいた自主的な展開が可能になると同時に， その教育研究活動は社会とのレリバンスの文脈でその可否が問われるようになったの である。

こうした䟇勢の中，理工系やあるいは文科系のなかであいわゆる「実学」(1) と目され る法学・経済学などはともかく,「文学部」の教育研究活動に対しては, 社会的有用性 の有無という観点から様々な批判がなされる反面, 人文学的教養の固守・伝達を求め る立場からは，その再生が唱えられている。つまり，人文科学は実社会のニーズとは 無緣の「虚学」であり, また文学部の人材養成の理念む曖昧だとして ${ }^{(2)}$, その存在理由 が改めて問い直されるべきだとの指摘がなされる一方で（水嶋 1995），一般教養教育 の見直しを直接的な動機として，文学部を拠点とした「哲学」復権の期待が語られ（今 道 1995)，またはさらに踏み込んで教養部にかわる人文学的教養機関の最後の砦と なるべきとの意見が提起されるのである（筒井 1995）。したがって，文学部をめぐる 評価は様々な批判と思惑が交錯した極めてアンビヴァレントなものにならざるを得な い。

しかしながら, いずれの議論も, 明治以来わが国の高等教育システムの中で, 文学

東京大学・大学総合教育研究センター 
部の歴史的道程を看過した状況的な印象論に終始している感がある。そもそも文学部 はどのような理念の下に創設され，高等教育システムの中でどう位置づけられてきた のか，またその研究一教育は何を期待され，どう変容してきたのか，そしていかなる 青年層を吸収し，また彼らはどのような社会的役割を担ったのか。こうした問題の解 明抜きにしては，現在の文学部をとりまく状況の分析はできないと思われる。しかし， これまでわが国の高等教育に関する研究では,「国家ノ須要」に応える法学や工学及び 医学などのいわゆる実学部門が中心的に取り上げられ，人文科学やまたそれを担うべ き文学部の機能と構造に関する包括的な研究は, ほとんど等閑視されてきたのであ $ろ^{(3)}$ 。

そこで，本論文では，以上のような問題関心の下，わが国の文学部の範型となった 帝大文学部（文科大学）の機能と構造を, 同じ文科系の法学部との比較, 及び東京・ 京都両帝大の比較を軸としつつ, その研究一教育面に焦点を絞り分析する。すなわち, 高等教育システムにおける文学部というセクションの構造 (第 2 節), 創立理念と学科 構成・カリキュラム (第 3 節), 学生の意識とエートスおよび卒業生の社会的配分と役 割（第 4 節）などの分析を通して，日本の近代化過程における文学部の専門教育の在 り方を解明し，現代の文学部が抱える問題群の淵源を探る。また本論文は，これまで ほとんど省みられることのなかった文学部に焦点を据えることによって，わが国の高 等教育研究に抜け落ちてきた隠れた領域を抉りだし，またそこから高等教育システム の全体像を逆照射する試みであある。

なお, 紙幅の関係上, 分析対象は明治初期から旧大学令（大正 7 年）までの東京・ 京都両帝大の文学部及び文科大学に限定し, 私立セクターについては折に触れて言及 するにとどめたい(4)。

\section{2. 高等教育システムにおける文学部の椿造}

まず，明治・大正期における高等教育システムの中で，人文科学を担う文学部がど のような位置づけをされていたのかを概観しておきたい。

旧大学令以前のみならず戦前期を通じて, 官立の高等教育機関（大学・尃門学校） には，独立した「文学部」は，この東京・京都両帝大以外には設置されることはなかっ た（東北・九州帝大は法文学部を設置）他の官立大学は, すべて理工系を中心として おり，実学系に偏重していたのである。この点は，明治以降の国家と人文科学との関 係を考える上で重要なポイントである。しかも，文科大学の卒業生（明治 9 年〜大正 7 年) は, 東大は 2,061 人で大学全体の $10.7 \%$, また京大 (332人) に至っては大学全体 
近代日本における「文学部」の機能と構造 の7.8\%に過ぎなかったのである（これに対し，法科大学卒業生は，その 4 倍近くに 上った。東大 $1986 \mathrm{~b}$ ，および『文部省年報』各年度版)。加えて, 両者とも全ての学 生を正統的なルートからリクルートできたわけではなかった。東京帝大の文科大学で は, 高等中学・高校から学生は思うように集まらず, 他の分科大学で実施されていた 進学のための競争試験はないどころか（東大 1986a，428頁), 学力検定試験などを 行って学生数を満たしていたのが実情であった。東大ですらこのような低迷状態で あったから, 後発組の京都帝大では文科大学を新設するのは「不急の業であるとの議 論」(京大 1956，6頁）が相次ぎ，その整備はなかなか進まず，実際に，旧制高校卒 業生では学生数が充足できず, 高等師範卒業生を受け入れ, 中等教員の再教育機関の 様相も呈することとなった

以上の事実は，いかに国家が人文科学を軽視していたかの証左でもある。では, 文 学というセクションが公私立に委ねられていたかといえば，決してそうではない。明 治・大正期において, 公立の専門学校・大学には,「文学部」は皆無であった。また私 立セクターの「文学」系の学校機関は, 実学としての (英) 語学, 女子の教養として の家政学, 神父・牧師養成のための神学，などの分野に特化した機関がその大多数を 占め, そうした学校群の中で, 明治20年代から曲がりなりにも総合的な「文学」教育 に関して一定以上の水準を維持し，明治36年に尃門学校として認可されたのは，東京 専門学校 (早稲田大学), 哲学館 (東洋大学), 國學院の 3 校程度に過ぎなかったので ある。しかも, その卒業生の数は, 他の学科に比べれば, 微々たるものであった。

以上のように，わが国の近代化の過程においては，文学部は，官立では東京・京都 の両帝大, 私立専門学校ではごく限られた数校にしか設置されていなかったのであ る。しかし，このように，近代日本の文学部が国家, 社会双方から軽視されてきた状 況は, 西欧各国と比較しても異様な在り方だったと言わなければならない。潮木が指 摘しているように, 「1900 60年までの間に, 各国の高等教育人口の総量 (に関して), ……最も高い增加を示したのは, 全ての国において, 人文科学だった」のに対して, わが国の近代化過程における「高等教育機関の発展は, ひとえに社会科学系統のみが とび抜けて独走するという，西欧的な発展の形とは著しく偏奇した形態をとって今日 に至って」（潮木 1973）おり，逆に人文科学は，一貫して軽視されてきたのである (天野 1995)。

こうした背景の理由としては，急速な富国強兵を推進したわが国の近代化の過程で は，その「後発効果」として，「国家ノ須要」な「実学」(法学・工学など) を偏重す る風潮が立身出世主義や地方中産階級の子弟の「教養」之結びっく形で（特に法学系 
私立), 青年の間に風摩していたからである（天野 1989）。またそうした志向は旧来 の和漢学を否定・排除するのみならず，西欧の人文学系の学問をも軽んずる方向に働 いたと考えられる（松宮 1992）。

では,こうした人文科学軽視の風潮の中で, 帝大の文学部は, いかなる理念の下に 創設され，それが研究一教育面でどう具現化され，また变容せざるを得なかったのか。 次章では, 帝大文学部の理念・学科組織・カリキュラムに焦点を当て, 時代とともに 摇れ動く文学部の在り方と現実的な対応について考察する。

\section{3. 文科大学における研究と教育}

\section{(1) 日本的「哲学部」と本邦古来の諸学の復具}

わが国の高等教育機関において,「文科」の名称が初めて登場するのは明治 3 年の 「大学規則」においてである。明治初年からの実学に偏重した政府の教育政策の中で, 「学科」の一つとして加えられたことは大きな意義を持っている。ただし，この規則に よる大学制度は, 和・漢・洋学三者の熾烈なへゲモニ一䦢争の中で実現することはな く, その後の「学制」(5 年) の大学規定では, 文学の名は削除されてしまっている。 翌 6 年の「学制追加」に「文学」は復活するすのの, その後の専門教育機関としての 東京大学の方向を決定したとされる「学制二編追加」(6 年) には, 外国語によって教 授する高尚なる専門学校として「文学」は明記されず，(東京）開成学校に「文学科」 は設置されなかったのである。

「文学」が初めて高等教育機関に組み込まれるのは, 明治10年, 東京大学の法文理学 部が創設されるまで待たなくてはならなかった。それは同学部の綜理に就いた加藤弘 之の力によるところが大きかった。加藤は，14年には東京大学総理，23年に第 2 代帝 国大学総長に就任し，一貫して草創期の東京大学一帝国大学の内部的指導者の立場に あり，10年代の「東京大学は加藤の大学」とまで称された（三宅 1950）。彼は，第一 科に史学科, 哲学及び政治学科, 第二科に和漢文学科を有する文学部を創設し，15年 には古典講習科を本科に付設したのである。

文学部を設置した加藤の目的は二つあった。一つには，「文学部中特二和漢文ノ一科 ヨ加フル所以八目今ノ勢斯文幾ント寒々晨星ノ如ク今之ョ大学ノ科目中二置カサレハ 到底永久維持スヘカラサルノミナラス自ラ日本学士ト称スル者ノ唯り英文ニノミ通シ テ国文二范乎タルアラ八真二文運ノ精英 7 収ム可カラサレハナリ」（東京帝大 1932 , 473頁）と，苟む日本の大学に自国の文学に通じた者を養成しないことなど考えられな いとして，まさに国家中枢の教育機関の文学部こそ本邦古来の諸学を再興・存続させ 
国学及び漢学の後継者養成の義務があるとするナショナリスティックな学問観に裹打 ちされたものだった（寺崎 1972）。

しかしその一方で, 加藤にとっての大学は,「理論高尚ノ一辺二泥マス実用浅近ノ一 辺二失セサルヨ旨ト（実学と虚学とを統合)」(東京帝大 1932, 473頁) するドイッの 近代大学に象徴される「諸学全備」の組織体でなければならなかった。近代大学は, 新人文主義的なフンボルト的理念一職業教育とは切り離された「学問の純粋理念」一 を標榜し，その下で, 法・神・医学部と同等の地位に昇格した哲学部が, すべての学 問に共通する哲学的・言語学的基盤を提供しそれらを統合するものとして，中核的な 位置を占めるべきものと措定されていた（Ringer 訳書 1991，1996)。したがって， 加藤は, 文学部をこの哲学部に擬し,「真理其物の為に真理其物を研究する学問とも云 ふべきものにして決して実用を以て目的とするものにあらざる」(加藤 1990)「哲学」 （政治学・史学を含む）に学問の総合性に立脚した指導原理を求めたのである（二見 1966) ${ }^{(6)}$ 。そして, 加藤の言葉を借りるなら, 啓蒙的な「学者」の養成を目指したので ある。

しかし，こうした加藤の目論見が首尾よく運んだわけでは勿論ない。12年には史学 科は学生・教官ともに人材を欠いているという理由で廃止, 18年にはドイッでは哲学 部內に置かれていた「政治学及理財学科 (14年に哲学科と分離・独立)」も法科大学へ と移管されてしまう。加えて, 自由民権運動との関連で哲学的思弁を撆戒する文部省 からは,「哲学」のカリキュラムに横槍が入り,「独り純正哲学ノミヨ講」ずることが あってはならず, 「主トシテカэ道義及心理学等二用七, 純正哲学ノ如キハ其概要二止 メ候事」と加藤に言質をとりつけるなど（東大 1984a，456-7 頁)，政府当局としては 文学部をあくまでも実用主義的な枠組みの中に位置づけ, 哲学（科）自体を他学部共 通の学問的基礎とすることはなかった。こうして，帝国大学に改組されるまでに，結 局, 哲学科は 9 名, 和漢文学科に至っては 2 名の卒業生を輩出したにすぎず, 両学科 ともに，本来の教育目的を十全に果たしたわけではない（ただし，古典講習科は数十 名の修了者を出し，その後の和漢学の大家を輩出した)。

ただ,ここでなにより重要なのは，加藤が文学部に「和・漢」と「洋」という相反 する理念を持ち込み，そうした学科を併存させたということである。それは，明治初 年からくすぶり続けてきた大学内の和・漢・洋三者の確執に対する加藤なりの配慮の 結果だったと言うべきであろうが，異質な理念に基づく学科の併存は，20年代以降の 文科大学の発展に大きな桎梏となっていくのである。 


\section{(2) 帝国大学令下の文科大学}

さて，19年には帝国大学令（栜令第三号）が制定，「帝国大学八国家ノ須要二応スル

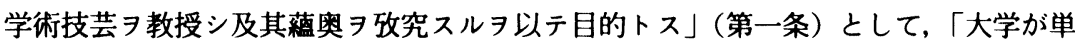
なる理論の為の理論の教授に止まらず，実際的要求に応ずべき使命を有すること…… 即ちその研究も教授も国家から遊離したものでなく，国家の為に役立つものでなくて はならない」(大久保 1943）と，その性格が規定された。文学部も文科大学として改 組され, 哲学科・和文学科 (22年に国文学科) ・漢文学科・博言学科が設置, 翌 20 年に 史学科・英文学科・独逸文学科, 22年には国史学科, 23年には仏高西文学科が増設, 合計 9 学科の研究一教育体制が整備されていく（37年まで）。また26年には，教授集団 の専攻分野を局限・深化させ研究と教育に責任を課す講座制の導入に伴い, 合計 20 講 座の研究ユニットが設置されることとなった（東大 1986a, 420頁)。

こうして，文科大学は20年代から30年代半ばにかけて，10年代のような不安定な形 態を脱し，本邦古来の国学系（国文・国史など）と漢学系（漢文・東洋史など），ドイ ツ哲学部の形態を模し純粋哲学の他に心理学・社会学・教育学・美学などを包摄する 哲学系, さらに西洋文学系の 4 系統の学科・講座が急速に開設・整備されていき, 現 在の文学部のほぼ原型を形成するに至る。

さて，それぞれの学科が，研究面においてどれほど国家の「実際的要求」に応えて いたのかは，学問分野ごとのさらなる精査が必要ではあるが，国学系は当時の「国粋 尊重の風潮」を背景に皇国護持の理論的支柱として（東京帝大 $1942 ， 188$ 頁)，また 漢学系はアジアの植民地経営のためのエリア・スタディとしての役割が期待された (東大 $1986 \mathrm{a}, 628$ 頁)。哲学系統も，加藤のみならず当時の帝大関係者に共有されて いた「万般ノ学理ヨ統一スル重要ノ学術」(渡透 1888) という認識を踏襲したもので ある。西洋文学系に関しては，その設置理由は必ずしも明らかではないが，語学と西 洋文明を紹介するという啓蒙的な役割が求められたといえよう。しかしながら，学問 (パラダイム) よりも制度の移植が先導されたため（中山 1974）, 法学系以外の多様 な学問分野が一挙に文科大学に放り込まれたという感は否めない。それは，哲学の意 味が拡大解釈され，哲学科がほとんど脈絡のない分野を包括していくプロセスに顕著 に表れている。当のドイッでは，19世紀後半には，哲学部の各ディシプリンは独立化 傾向にあり，諸学統一の理念も形骸化していたから（別府 1975，関 1994，1995), この哲学科の方向は，ある意味で時代錯誤的だったとも言える。しかも，各学科は学 問の制度化の必然として，また学問の藴奥を極めるという錦の御旗の下に，それぞれ 専門的研究への傾斜を強め, 各学科間の壁は次第に厚くなっていくのである。しかも, 
30年代半ばに至るまで，教授集団の出自・世代・教育背景などは極めて多様であり， 和・漢・洋の確執が根深く続いていた（橋本 1995）。こうした混沌とした状況を統括 する責を負っていたのが文科大学長であったが，漢字廃止論者として知られた初代外 山正一（30年まで。外山 1909）は，国学・漢学の教授陣とは絶えず衝突して古典講 習科の卒業生を罵倒し（三上 1991，31 頁), 第 2 代の井上哲次郎（M31～37）も, 主 に哲学科の充実に努めたものの, 他の学科の整備はほとんど顧みなかった（三上 1991，123頁。井上 1973)。したがって, 研究面では, 組織的にはともすれば学科ご とにバラバラになる可能性を㔔んでいたのであり，また内容的に一個の学問領域とす るには余りに統一性を欠いていたのである。

また教育面では，発足当初には官僚養成を目的とした法科大学のように（中山 1978), 政府一文部省が文科大学を中等教員養成を主眼とする, より社会的レリバンス の強い実用的機関とする方向がなかったわけではない(寺崎他 1991)。しかしそうし た方向はすぐに放棄され，現実的には帝国大学令の下で専門分野の藴奥を極めた研究 者養成が最大の目的となっていく。それは, 10年代の加藤の夢想する「学者」養成の 理念がより現実的な形を整えてきたとも言える。しかし，10年代から20年代前半の卒 業生の多くは，高等教育機関での研究職を約束され，特に文科大学の邦人教授の第 2 世代を形成したが（橋本 1995）, 20年代後半からは, 専門的研究者としての市場は早 くあ狭隆化していき，卒業後そうしたポストに就くことが出来る者はほとんどいなく なる(7)。また，学生は，入学時に専門学科を選択しなくてはならず， 3 年間の授業は, その学科ごとに縦割りに綿密に決められ, 他学科の自由な聴講は事実上不可能である など, 一種の囲い込みが進んでいき，ますますその専門的知識が生かせる場は限られ ていったのである。しかし, 大学や学科側が, そうした状況に対応して卒業生の適切 な社会的配分を考虑していたわけではなかった。

こうして，20年代後半以降，文科大学は研究一教育体制を整備していくが，同時に それは研究組織や学問内容としては細分化・専門化し, また研究者養成という教育目 的が就職市場と不協和音を生じていく過程でもあったのである。

\section{（3）明治37年の大改革}

しかし，こうした研究・教育体制を变革する動きがなかったわけではない。37年に 断行された改革は、多様な学科に分化した研究組織を統合し教育面であ社会的レリバ ンスを重視する方向を打ち出すなど，それまでの文科大学の在り方に大きなメスを入 れるものだった。すなわち、これまで 9 学科に分かれていたものを哲・史・文の 3 大 
学科に再編・統合し，従来の学年制による固定的なカリキュラムや在学期間の制限を 廃止して, 学生の自由選択による単位制へと移行させ, 外国語 2 力国語の試験合格を 卒業試験受験資格としたのである。

研究面では，諸学科を統合するとともに新たな学科增設の道を開き，教育面では学 生を「一個の紳士として遇す」(『教育時論』 1904)としながらも，過酷な外国語試験 を卒業要件とした点で,「ドイッ大学の制度に則つたもので頗る自由」(東京帝大 1942，191頁）でラディカルな改革であった。この大改革を推進したのは，同年井上哲 次郎の後を襲った第 3 代学長坪井九馬三である（東京帝大 $1942 ， 199$ 頁)。坪井は, ベルリン大学などでのドイッ留学から㷌国後史学科の教授の地位にあったが, 自らが 在籍・体験した古典的哲学部之聴講生制度に強い思い入れがあったものと考えられ る。同時に, 学長就任早々「文学は琴書に等しく候事, 語学の修養こそ遥かに必用に 御座候」という訓戒を張り出したことからあ推察されるように（XY生 1905), 研究 ポストが閉塞しつつある状況にあって, 語学能力を就職の際の付加価値と捉え, 実用 的な語学教育を重視したと言える。そして，彼は，30年代前半に起こった教授集団の 世代交代を背景としてこの改革を断行したのである（橋本 1995）。ただし，この文科 大学の改革が, 同時期の京大法科大学におけるドイッ式カリキュラムの改革・実験 （潮木 1984）と，よ゙う絡み合っていたのかは残念ながら不明である。

しかし，たとえば史学科は，国史，東洋史，西洋史といったこれまでの和・漢・洋 に分裂していた分野を包括しなくてはならないなど，この改革は組織的にはもともと 無理な側面があり，統合とはいってもどれほどの効果があったのかは疑わしい。また 学生のなかには専攻を決定しないまま修学年限の延長を絽り返したり, 過酷な語学試 験によって何度も落第する者が続出するなどの慗害が顕になってきた。その結果, 43 年 9 月には, 早くも再改正を余儀なくされ, 専修学科は 2 年の初めまでに決定, 外国 語の履修要件は 2 年間に短縮, さらにその試験は学科によっては 1 力国語であ良いと するなど，専門研究重視への摇り戻しと外国語の負担轻減が図られたのである。また 坪井む, 外国語試験に落第した学生が自殺するなどの事件が起こり，その対処の不手 際に対する内外の批判が高まり(『東京朝日』1911), 学長退任（45年）の契機となっ た。こうして, 学問分野統合の実験と社会的レリバンス重視の教育を目指したドイッ 式大改革は失敗に終わり，その後文科大学は，ますます専門分化が加速化され，学科 毎の綎割りのカリキュラムが強化されることとなったのである。そして大正 8 年, 文 学部に改組された折に，ついに哲・史・文の 3 学科体制は崩壊し，19学科が乱立する こととなる（戦後，再び統合・分裂が繰り返される）。 
近代日本における「文学部」の機能と構造

さて,こうしてみると, 30年代後半は, 文科大学のみならす帝国大学の研究一教育 における自己改革の時期に当たっていたといってよい。そうしたなか，京都帝大に文 科大学が新設される。京大は，いかなるシステムを採用したのか。

\section{（4）京都帝大の創立}

京大文科の基礎を築いた初代学長は，一高校長から拔擢された狩野亨吉であるが， 唯物論的合理主義者（高橋 1993）であり, 哲学者に対する根本的不信を抱き（久野 1947)，濑石には「文学亡国論者」と言われた狩野（阿倍 1958）が，文学部の研究に どれほどの役割を期待し，またどのような教育理念をもっていたのかは残念ながら定 かではない。しかし，少なくとも初代総長の木下広次以来打ち出された研究中心主義 という特色を文科大学も踏散し、また実際にそれをカリキュラムにあ具現化しょうと したことは確かである。つまり，哲・史・文という東大の統合的な 3 学科制は踏襲し つつも, 研究面では, 内藤湖南など在野からの教授登用や, 心理学科・地理学の独立 講座化, 東洋 (史) 学の重点化, 邦人教授のみによる西洋文学講座の開設などを推進 し，また教育面では哲・史・文それぞれに属する正科目と副科目を定め, 学生には正 科目全部にわたって普通講義を必修させ，更にその内の 1 科目を専攻科目として選 択，その特殊科目と演習を履修させるシステムを構築した。また，ほとんどの副科目 は学生の自由聴講に委ねられ, 在学期間も6 年までと制限され, 学年制こそ採用して はいなかったが， 1 年目は専攻を決定することなく暂・史・文全般に関する普通科目 を履修することが要求された。また, 外国語の履修は, 文学科では一部必修とはなっ ていたものの, 全て副科目として学生の自由聴講に委ねられていた。こうして, 語学 に偏した実用的な教育を否定し研究に重点を置きながらも，学生の「研究が早くから 専門に偏する傾向を是正」(京大 $1956 ， 10$ 頁）することを第一義としたのである。

狩野が東大文科や京大法科の改革をどう把握していたかは明らかではない。ただ, 同時期の東大文科の統合的な研究組織と自由聴講制を導入しつつも，あまりにラディ カルなために破綻しつつあった東大方式を一部修正し，現実的な適合を試みたことは 確かである。狩野は, 東大とは異なる特色を出そうとするあまり, 文部省と衝突, 病 気を理由に在職 3 年にして隠退するが，戦後に至るまで狩野が構筑したシステムは引 き継がれていく。このように, 京大方式がある意味で成功裏の内に定着したのは, 教 授集団の大半が東大文科卒業の学士であり, 身分的にも均質であったと同時に, 和・ 漢・洋の因習的な確執からも自由であったことが，その理由の一つとしてあげられる (橋本 1995)。 
しかし, その成功は研究面に限られていたと言ってよい。卒業後の研究ポストが充 分に保障されていたわけではないことは東大文科の状況と何らかわりなく, 自由な研 究重視というモットーも，無責任な教育放任主義に堕す危険性を孕んでいたと言うべ きである。

こうして, 文学部は近代化の過程において, 明治以前からの学問的伝統の継承とそ の確執, 哲学 (部) 理念の移植と破綻, 学科組織の統合と分裂の㗨張, 研究中心主義 への傾斜とポストの不足, 教育の社会的レリバンス重視とその失敗, などその設立当 初から，理念と現実の間で摇れてきたのである。では，こうした研究一教育体制は， どのような志向を持った学生に受容され, また彼らはいかなるエートスを内面化して いったのか, 研究者のポストが閉塞化する中で彼らはどう社会的に眍分され, またど のような役割を果たしていったのか。次節では，これらの点を中心に考察する。

\section{4. 社会的配分}

\section{(1) 学生のエートス}

明治20年代半ば, 東京専門学校文学科の関係者からは, 「小生従来切りに同校 (東大 文科）の学生の気風に目をつけ，そも何を目途として学問を為し居るかと考へ候処， 心の底はいざ知らず兔に角打見たる所にては別段是と言ひて確定したる望みとては無 之様子に御座候。まづまづ卒業して学士号を得て扨云々せんと言ふがさしあたりての 目的らしく相見え申候」(南山生 1891) と挪揄されたように, 文学部が立身出世には 関心が薄い青年層を吸収し, 特に明治 30 年代後半には, 法科万能主義が風權していく 中で， 日露戦争後に登場したと言われる文学や哲学に沈潜する煩閖青年 (Kinmonth 訳書 1995）の多数を収容していったことは想像に難くない。大正半ば, 三高から東 大文科に進学した学生は, その進学理由を,こう回想している。「今や如是閑や雷夢の 影響でかなり心の決まった思想青年, 文学青年になっていた。で, 「人生如何に生くべ きか』というような問題で年中煩閆していた。……こうなっては，あはや官界や実業 界に出て成功しようなどとは思えなくなった。考えた末, 帝国大学の文学部というこ とに決めた」(本田 1970，100-1 頁)。

こうした立身出世主義に距離を置く学生らの志向は，人気がないがために実現した 小人数の研究室を単位とする「私塾的」(京大 1956, 643頁) な教授一学生関係を通 し ${ }^{(8)}$ ，教授らの文人的な気風と相まって（橋本 1995）, 研究を主体とする一種独特の エートスへと止揚されていく。

「当時 (大正初期) の学生は学問を研究せんとする志に燃えて入学していて……就職 
近代日本における「文学部」の機能と構造 の為の職業を求める手段として入学したと謂う様な考は殆ど無く……卒業生は中等学 校の教員の資格の免許状取得が出来たが, 資格がありながら申請せぬ者もあり, 往々 中学校教員には決して従事せぬと傲語する者すらあった」(京大 1956, 466-7 頁), あ るいは,「(大正の半ば) 就職ということは第一の問題ではなかった……何とか勉強を つづけて行こうというのが一般の気風であったように思い返される。 一種の哲学 熱が一方にあったということもわりに就職の問題に対して吾々を無頓着にさせていた のかも知れない」(京大 1956，516-7 頁)，などの卒業生の回顧からも垣間みられるよ うに, 文学部は教職などの職業教育とは無縁の学問を研究する場であり, 生涯にわ たって「研究する」態度の受容がその教育の第一義だとする意識が形成されていった のである。

その結果, 文学部の卒業生は, どのような職業に就こうとも,「研究」がその生活の 根底を支える基盤となっていたと言える。「私自身としては平素その精力を挙げて日 本仏教史の研究に従っているわけですが, 未だこれといふ進境はない（文部省宗教 局)」(東京帝大文学部 1929，98頁)。「専攻の学をこつこつと続けているといふだけ で, 別に变わったことも無之候 (浦和高校)」(東京帝大文学部 1931，115頁),「拝啓 卒業後唯教職に従事致すのみにて格別の研究す遂げず残念に存じ居り候（愛知津島中 学)」(東京帝大文学部 1929,52頁),「……当地へ転勤致し法律の適用に忙殺せられ て文学研究の余暇なく閉口致し居り候（朝鮮群山府裁判所判事)」(東京帝大文学部 1929，60頁）といった卒業生の近況報告からは,「研究のためのパン」といった共通し た意識が看取できるのである。

では、こうしたェートスを内面化させた学生は, 卒業後, 具体的にはどのような進 路を取りまたいかなる役割を果たしたのだろうか。

\section{（2）社会的西分と役剖}

まず, 文学部の当年度卒業生の進路先とその変化としては, 東大の場合 (『文部省年 報」各年度版および, 東大 1985), 明治20年代前半に一定数存在した「行政官吏」や 「大学講師」が30年代以降はほとんどいなくなること，またそれぞれの割合に多少の変 動はあるものの,「学校教員」(4 割) と「学生」(3 割：大学院生・研究生・他分科大 学学生など）および「未定者」(2 割) の 3 カテゴリーに大別されることなどが指摘で きる。

ただし，以上のデータでは学校教員の内訳や大学院生などの就職先が不明なため, 文学部卒業生の社会的配分の全体像が把挃できない。そこで, 東大では『東大文学部 
学友会会員名簿』(東京帝大文学部 1928) を利用して, 明治19年から大正 7 年までの 全卒業生 $(2,014$ 人) の就業状況（大正末現在＝ほぼ大学院生が就職した時点）を分析 してみると, 死亡者 (313人) を除けば, 最も多いのが中等教員であり $(29.8 \%$ ：ただ し, そのほぼ 4 割は校長職), 続いて旧制高校教員 (19.6\%), 不明者 $(12.2 \%)$, 帝大・ 官立大学教員 $(9.7 \%)$, 私立大学教員 $(6.5 \%)$, 官公庁 $(4.1 \%)$, 官公立専門学校教 員 (3.5\%) となっている。したがって, 全体のうち 7 割 5 分が学校関係者であり, 官 公庁, 銀行会社員 (2.7\%) などは極めて少ないことがわかる。また京大の場合, 『学 士会名簿』(大正16年度版) を分析すると，明治 42 年から大正 7 年までの全卒業生 330 人のうち，不明・死亡などを除く 178 人の就職先は，中等教員 $(17.4 \%)$, 不明 (16.3\%), 旧制高校教員 $(13.5 \%)$, 官公立専門学校教員 $(10.7 \%)$, 帝大・官立大学 教員 $(5.6 \%)$ などと続いている(9)。

こうしてみると, 両帝大に多少の差はあるものの, 卒業者の全てが尃門的研究者で ある大学教員などに就いていたわけではもちろんなく，それ以外の進路として中等教 員と旧制高校教員がその半数を占めていたことがわかる。ただし，当時の中等教員全 体から見れば, 文学部卒業生の比率は, 数パーセントに過ぎず, 極めて限られてい だ。その一方で, 旧制高校に関しては，その校長・教授全体の実に 6 割近くを帝大文 科出身者が占めていたのである゙すししたがって, 両帝大の文科大学は, 大学レベルの研 究者養成という側面は当然としても，旧制高校での教養主義的な教育に果たした役割 は極めて大きかったと言わなければならない。また，戦前期の教育システムにおける 初・中等段階での「教育」(顕教) と高校以上の「学問」研究（密教）という二面性を 考えあわせれば（寺崎 1988）, 前項で見たような文学部卒業生の「研究」するという エートスは，中等レベルでの教職よりも，旧制高校においてこそ最も効果的に発現し たと言える。

ただし，旧制高校は，本来，人文科学を主体とする教羪教育機関としてではなく， 偏に中等教育と帝大の外国語教育のギャップを埋めるべく設置されたのであり，「全 くの外国語学校」(中川 1977) とさえ形容された機関であった。文学部の卒業生は, この機関に主に語学などの教官として赴いたが，彼らは「語学を教えるためというよ りは（高校生に）人間の大きさや人生のなんたるかを学ばせ，それを通じて学問のや り方に目を向けさせ」(河北新報社編 1977), 原昰講読を通じて西欧の哲学・思想・ 文化・文学を教授したのである。そして高校生は，それらをコアとしてェリートの学 校文化たる教養主義を形成していったのである（寺崎 1993，橋本 1990)。さらにつ け加えるとするなら，官学セクターにおける高等教育は，高校での人文科学偏重と大 
近代日本における「文学部」の機能と構造

学での「実学」重視という点で, 期せずして巧妙なバランスが保たれていたと言える のである。

\section{5. おわりに一まとめと今啳の目昌-}

以上，わが国の近代化過程における文学部について，その研究一教育の在り方を軸 に，考察を進めてきた。分析対象を明治から大正半ばまでの帝大文学部という官立セ クターに限定し，また個々の学問分野に関してもインターナルな分析を行っているわ けではないが, 従来の高等教育（史）研究ではほとんど看過されてきた文学部に関し て，いくつかの新たな知見が得られた。すなわち，わが国の近代化の過程では，官立・ 私立ともに文学部を有する機関は極めて限られており, 国家・社会の双方から軽視さ れてきたこと, 帝大文学部はその設立当初から本邦古来の諸学復興とドイッ哲学部の 模倣という和・漢・洋の相反する志向を抱えた暧昧な組織体であり，そのため学問の 制度化とともに学科相互の壁が厚くなり「人文科学」と一括りにはできない学問領域 が出来したこと，また帝国大学令下で研究者養成を最大目的としつつも市場との関連 でその教育目的はすぐに行き詰まったこと，そうした研究一教育の閉塞状況に対処す るため学科組織の統合や語学重視のカリキュラム改革が断行されたが, 結局失敗に終 わり，学科毎に研究への傾斜がますます加速化されたこと，しかしその一方で文学部 は立身出世とは無縁の少数派の文学・哲学青年を吸収し, 文人的な教授による小人数 教育を通じて，生涯にわたり「研究する」というエートスが形成されたこと，またそ れは旧制高校で効果的に発現し, 文学部の卒業生がその教員として教養主義教育に果 たした役割は極めて大きかったこと，などを解明した。

つまり，逆説的に要約するなら，わが国の近代化過程における文学部は，社会的需 要が少なく，かつ高等教育もエリート段階に止まっていたが故に，理念や組織面での 破綻の危機に常にさらされつつも，その研究と教育は，教授と学生との親密な関係の 中で巧まずして統合され，人文主義的教養の創出に重要な役割を果たし得たのだと換 言できる。しかし，このことは，裹返せば，高等教育がエリート段階を脱し大䍃化が 進めば進むほど, 文学部はそうした教育一研究機能を十全に果たし得なくなっていく ことを意味している。

実際，旧制高校が各地に続々と增設され文学部にも大量の学生が流入する昭和初 期, その研究一教育の在り方は大きく変容する。当時, 京大文学部に在学した学生は, こう回顧している。「文学部の各学科とも, 昭和二年頃から卒業生が激增している。 ……それはただ学生が增えたというだけでなく, 今までの教授一対学生一, 二という 
云わば師匠と弟子という形から，もっと量産的，組織的な授業への推移を意味した。 ……教授陣の入れ替わりもあずかって，研究室の気風も一新された」（京大 1956 , 519-20頁)。

さらに言えば，こうした傾向は，戦後のマス化過程で，ますます拍車がかかって いったはずである。国公私立を問わず多数の大学に文学部が設置されていくととも に，文人的な教授陣は姿を消し，また一般学生（Ben-David 訳書 1982）が大半を占 めるようになって文学・哲学青年は1960年代以降には少数派になってしまう（渡辺 1985)。こうした通勢においては，旧来の文学部の機能や役割は，もはや望むべくもな い。つまり，現代の文学部は，エリート段階においてこそ機能し得る統合的な研究一 教育体制をマス化した高等教育の中でどう維持・再生させるのかというアポリアを孕 んでいると言えるのである。

しかし, 大正後期以降の文学部の变容を跡づけ, 現代の問題群の処方にまで敷延す ることは，すでに本論文の当初の目的を大きく越えている。したがって，今後，以上 の知見を踏まえ，時系列的には，高等教育機関の拡張期にあたる昭和戦前期，および 戦後のマス化過程における文学部の機能（特に女子の高学歴化に果たした役割）の分 析が，また横断的には国内の官立一私立セクターのみならず諸外国との比較におい て，わが国の文学部の特徵に関する考察が，さらには文学部における各学問分野の知 識社会学的あるいは科学社会学的な分析を通じて，人文主義的教養の解明が進められ なければならないが，そうした考察は他日を期することとしたい。

〈注〉

（1）ただし，ここで言う「実学」とは，社会的有用性があるとみなされる学問という 意味あいであり，歴史的概念である「実学」とは異なることに注意（源 1986）。

（2）個々の大学白書における文学部の自己評価については, 橋本 (1995), 参照。

（3）『学士会名簿』(大正 9 , 昭和 5 年度版)を利用した文学部卒業生のキャリアパター ンについては, 山田 (1994), 東大文学部の成立過程に関しては, 大川（1993）を参 照。また山内（1995）は，文学者の考察から文学部に言及している。

（4）私立セクターにおける卒業生の社会的配分の分析は, 橋本 (1996), 参照。

（5）東大の場合，明治30年から大正 4 年までの本科入学者の内訳は，旧制高校卒業生 が $88 \%$ ，検定試験によるものが10\%，その他 $2 \%$ とっている。また京大の場合 (明 治39年〜大正 6 年）には，旧制高校卒業者は，60\%程度に止まり，高師卒業者が $25 \%$ ，検定などその他が15\%程度となっている（各年度の「官報」および各大学一 
覧から集計)。

（6）ただしここで加藤の言う哲学（部）とは，19世紀後半のドイッにおいて自然科 学系の学科が「理学部」として独立した後のいわゆる「文学部型哲学部」をモデル としていたと考えられる。別府（1975）参照。

（7） 26 年には初めて「就職未定者」が登場する（『文部省年報』明治26年度版）。

（8）たとえば，旧大学令施行直前の大正 7 年, 東大文科は19専修学科29講座を有して いたが, 当年度卒業生は 82 人で 1 学科あたり 4 人強, また同じく京大文科では, 21 専攻24講座で38名であり，1専攻あたり1.8人に過ぎなかった。

(9) 詳細に関しては, 橋本 (1996), 参照。なお京大に関しては, 信頼に足る卒業生名 簿が未発見のため,『学士会名簿」を利用した。

(10) たとえば大正 15 年度の全国の中等学校教員数は39608人（『文部省年報』大正 15 度 版)，そのうち両帝大の文学部卒業生の割合は1.9\%にすぎない。

(11) 成蹊高校を除く 28 校の全教授数 791 人中 463 人 (58.5\%) (大正末年の各高校一覧か ら集計)。

\section{〈引用・基考文献〉}

阿倍能成編 1958, 『狩野亨吉遇文集』岩波書店, 199頁。 天野郁夫 1995, 「高等教育の日本的構造」『21世紀フォーラム』No. 53。 — 1989, 『近代日本高等教育研究』玉川大学出版部。

Ben-David,Joseph 1977, 天城勲訳『学問の府』サイマル出版会, 1982。 別府昭郎 1975,「19世紀ドイッ大学哲学部における研究教育体制の变容」『歴史評論』 No. 301 。

二見剛史 1966,「日本近代大学成立史の研究 (その1)」『九州大学教育学部紀要』第 12集, 24頁。

橋本鉱市 1990, 「近代日本におけるエリート養成の教育過程一旧制高等学校の教養 主義教育について一」『東京大学教育学部紀要』第30巻。

- 1995,「わが国における文学部の機能と構造（1）一帝大文学部の教授集団 の分析を中心として一」『東京大学教育学部紀要』第35巻。

— 1996,「明治・大正期における文学部卒業生の社会的配分と役割」『大学史 研究』第12号。

本田喜代治 1970, 『旃陀羅の子」法政大学出版局, 100-1 頁。 今道友信 1995,「大学における教羪教育」「IDE』No. 370。 
井上哲次郎 1973, 『井上哲次郎自伝』富山房。

河北新報社編 1977, 『天は東北一第二高等学校物語一』河北新報社, 90 頁。

加藤弘之 1990 , 『加藤弘之文書 第三巻 講演全集第三冊「学問の目的」』同朋社, 409-10頁。

Kinmonth, E. H. 1981，広田他訳『立身出世の社会史』玉川大学出版部，1995。

久野収 1947, 「狩野亨吉」『中央公論』4月号, 70頁。

『教育時論』1904，第六百八拾壱号（3 月15五日付)，28頁。

京都大学 1956, 『京都大学文学部五十年史」。

松宮秀治 1992,「日本における『芸術』の受容」『立命館言語文化研究」 4 巻 1 号。

三上参次 1991，『明治時代の歷史学界 三上参次懐旧談」吉川弘文館。

源了圓 1986, 『実学思想の系譜』講談社。

三宅雪嶺 1950，『自分を語る』朝日新聞社，128頁。

中川善之助 1977 , 「旧制高校の青春と教育」『わが青春旧制高校」ノーベル書房, 76

頁。

中山茂 1974 ,『歴史としての学問』中央公論社。

1978, 『帝国大学の誕生』中央公論社，74-97 頁。

南山生 1891, 「文科大学」『早稲田文学』第一巻, 18頁。

水嶋一憲 1995,「旅する文化, 転位する人文学」『人文学のアナトミー」(山田他編)

岩波書店。

大川一毅 1993,「近代日本の大学における『文学部」の成立について一東京大学「文

学部』を中心にして一」『フィロソフィア」第80号。

大久保利謙 1943,『日本の大学」創元社, 321-2 頁。

Ringer, Fritz 1969, 西村稔訳『読書人の没落』名古屋大学出版会 1991。

1992, 筒井清忠他訳『知の歴史社会学』名古屋大学出版会 1996。

関正夫 1994，「現代大学における教育改革の一方向」「大学論集」第23集。

1995,「社会の变動と学問・教育等への影皚」「大学論集」第24集。

高橋英夫 1993,『偉大なる暗闇」講談社, 183頁。

寺崎昌男 1972, 「帝国大学形成期の大学钼」「学校観の史的研究」講談社, 225頁。

- 1988,「日本の近代化過程における「知」の眍分と統合」「日本の教育史学」 第31集。

—他 1991, 『御雇教師ハウスクネヒトの研究」東京大学出版会。 1993，「旧制高校教育研究の視座」「近代日本における知の眍分之国民統合」 
第一法規。

『東京朝日新聞』1911, 「文科大学問題」，10月 6 13日付。

東京大学 1984a,『東京大学百年史 通史一』。

- 1984b, 『東京大学百年史 資料一』。

——1985,『東京大学百年史 通史二』, 179頁。

- 1986a, 『東京大学百年史 部局史一』。

— 1986b, 『東京大学百年史 資料三』, 483-5 頁。

東京帝国大学文学部 1928，1929，1930，1931，『学友会会報』。

東京帝国大学 1932,『東京帝国大学五十年史 上冊』。

— 1942, 『東京帝国大学学術大観 総説・文学部」。

外山正一 1909,『、山存稿 後編下』丸善, 146-156頁, 180-189頁。

筒井清忠 1995, 『日本型『教養』の運命』岩波書店, 173-8 頁。

潮木守一 1973, 『近代大学の形成之变容』東京大学出版会, 187-9 頁。

— 1984, 『京都帝國大学の挑戦』名古屋大学出版会, 110頁。

渡尰洪基 1888,「帝国大学第三回卒業証書授与式（明治 21 年 7 月）」（東大 $1984 \mathrm{~b}$, 1057頁, 所収)。

渡辺一民 1985 , 「文学部の専門教育」『大学における専門教育の問題点』(J. U. A. A. 内外大学関係情報資料 9）大学基準協会。

XY 生 1905, 『文科大学学生生活」今古堂書店, 81頁。

山田浩之 1994,「帝国大学文学部卒業生のキャリア一高等教育機関での移動を中心

にして一」『松山大学論集』創立70周年記念論文集。

山内乾史 1995, 『文芸エリートの研究」有精堂。

【なお, 本論文は, 平成 7 年度科学研究費奖励研究(A)（「近代日本における文学部の 教育内容とその社会的機能」) の成果の一部である】 